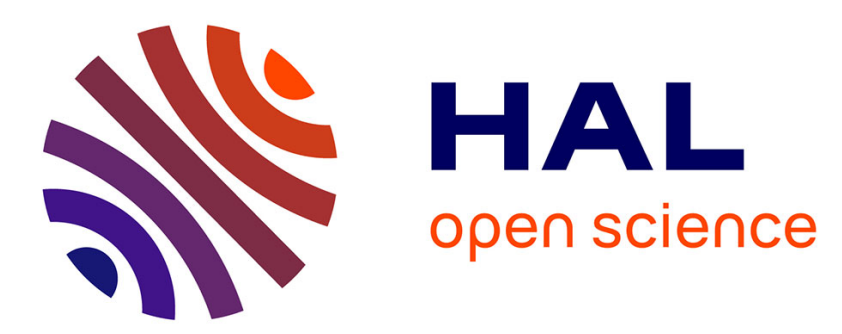

\title{
A comprehensive approach to assessing PV system economics and opportunities for PV policies
}

Hyun-Jin Julie Yu, Nathalie Popiolek, Patrice Geoffron

\section{To cite this version:}

Hyun-Jin Julie Yu, Nathalie Popiolek, Patrice Geoffron. A comprehensive approach to assessing PV system economics and opportunities for PV policies. EEM15 - 12th International Conference on the European Energy Market, May 2012, Lisbonne, Portugal. cea-02509720

\section{HAL Id: cea-02509720 https://hal-cea.archives-ouvertes.fr/cea-02509720}

Submitted on 17 Mar 2020

HAL is a multi-disciplinary open access archive for the deposit and dissemination of scientific research documents, whether they are published or not. The documents may come from teaching and research institutions in France or abroad, or from public or private research centers.
L'archive ouverte pluridisciplinaire HAL, est destinée au dépôt et à la diffusion de documents scientifiques de niveau recherche, publiés ou non, émanant des établissements d'enseignement et de recherche français ou étrangers, des laboratoires publics ou privés. 


\section{A comprehensive approach to assessing PV system economics and opportunities for PV policies}

\author{
Hyun Jin Julie Yu \\ Nathalie Popiolek \\ Institute for techno-economics of energy systems (I-tésé), \\ Direction de 1'Energie Nucléaire \\ Commissariat à l'Energie Atomique et aux Energies \\ Alternatives (CEA) \\ Gif-sur-Yvette, France \\ julie.yu@cea.fr
}

\author{
Hyun Jin Julie Yu \\ Patrice Geoffron \\ Laboratory of Economics (LEDa) \\ Centre of Geopolitics of Energy and Raw Materials (CGEMP) \\ Chair of European Electricity Markets (CEEM) \\ Paris-Dauphine University \\ Paris, France \\ hyun-jin.yu.11@campus.dauphine.fr
}

\begin{abstract}
The price of PV modules has fallen below \$1/Wp in many countries. Non-module prices have become critical factors to assessing PV system economics. This study sets out to review the price of residential PV systems in a comprehensive manner while looking for cost drivers to improve their economic competitiveness. The relation between the market size and price drop in the non-module sector is reviewed in this paper. In addition, this article investigates opportunities for using policy instruments to help reduce non-module costs of PV systems in Europe (e.g. standardization, etc.). In doing so, it shows how harmonized policy instruments on a regional level can reduce non-module prices of residential PV systems in Europe by benefiting from the experience of German practice (e.g. low nonmodule prices) and the size of the European market.
\end{abstract}

Index Terms - economic forecast, international collaboration, power generation economics, public policy, photovoltaic (PV) systems

\section{INTRODUCTION}

PV energy has demonstrated visible progress over the last decade, reaching 150 gigawatts $(\mathrm{GW})$ of installed capacity in early 2014. It is forecasted that $16 \%$ of global electricity will be provided from solar PV energy by 2050 [1]. Over the past few years, the PV market conditions and PV system prices have evolved rapidly. The reduced cost of PV modules has contributed to enhancing the economic competitiveness of PV systems. Non-module prices are not, however, declining proportionally with the module price drops everywhere and therefore present an obstacle to the economic competitiveness of PV systems [2]. PV system prices vary from country to country according to their different political contexts.

Therefore, this study attempts to review PV system prices to understand cost drivers and then look for ways to further reduce costs to improve the economic competitiveness of the future PV systems. In addition, this paper explores opportunities to deploy useful policy instruments to help reduce non-module prices in PV systems in Europe.

\section{OPPORTUNITIES TO IMPROVE PV SYSTEM ECONOMICS}

A. Systemic approach to asssessing the economics of $P V$ electricity in a society

Defining the PV electricity price structure in a comprehensive manner is a critical way to identifying both cost drivers for each segment and possibilities for implementing policy instruments to improve them.

$\mathrm{PV}$ power is commonly priced as levelized costs of electricity $(\$ / \mathrm{kWh})$. Solar PV system costs are one of the important levers when defining the initial investment needed to calculate the levelized costs of PV energy (LCOE). LCOE will also depend on other factors like module efficiency, capacity factor, cost of capital and lifetime.

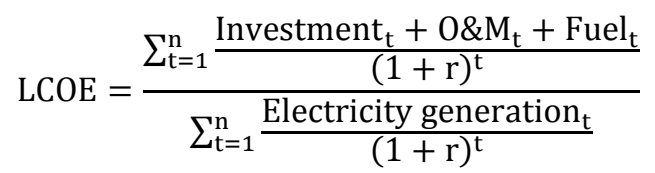

This perspective should be broadened to include grid-level costs and externalities for real economic assessment of PV electricity in a society.

Grid-level costs ${ }^{1}$ refer to all additional costs required for grid integration into the energy system [3]-[4]-[5].The impact can be significant in the case of the widespread penetration of PV systems. Externalities refer positive or negative effects, which have yet to be internalized into the PV system price. They influence the national energy system and social welfare with respect to PV penetration into the energy system. There are various aspects to be considered: environmental, electricity market, technology, economic and energy position [3]-[6].

Each country has different PV system economics according to the national energy system features and political choices. The PV electricity generation costs in a society can by reduced by implementing a political mix from the following strategies:

- Minimize PV electricity costs

\footnotetext{
${ }^{1}$ These costs include grid reinforcement and extension. The characteristics of intermittent PV electricity can also add costs related to short-term balancing and long-term adequacy while being integrated into the existing energy system.
} 
- Minimize grid integration costs and risks

- Maximize net benefits of externalities (positivenegative) affecting social welfare as PV penetration progresses.

In this article, strategies for minimizing PV electricity costs are only discussed with a focus on the non-module sector. The objective is to find out ways of implementing further reduction strategies to reduce PV system costs by reducing non-module prices in PV systems. However, maintaining a systemic point of view is extremely important with respect to PV political choices and implementation issues.

\section{B. Importance of non-module prices in PV system prices}

The PV system price is a key variable of the initial investment when calculating PV electricity costs. Until recently, the reduced module prices were the most focused driver to enhance the economic competitiveness of PV electricity. Research and industry has striven to decrease module production unit costs through cell efficiency improvement and economies of scale. Over the last decade, the PV system price drop was mainly correlated with the module price reduction.

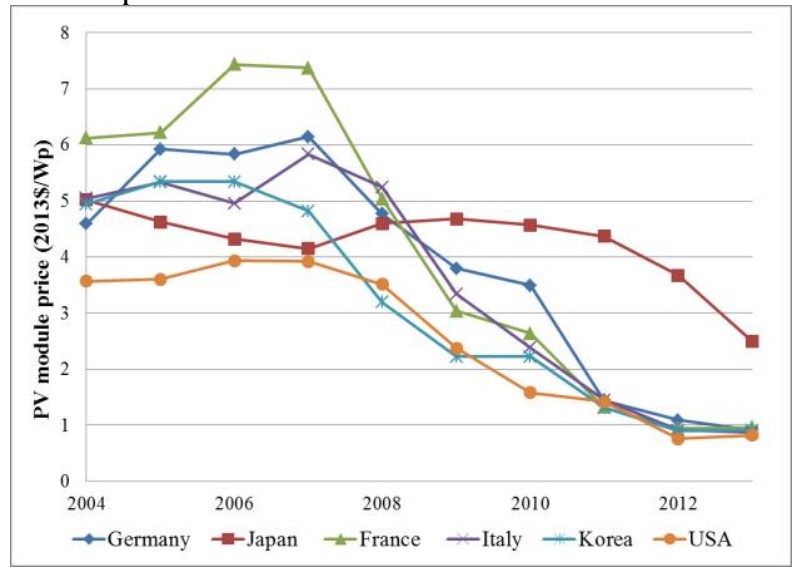

Figure 1: Change over time in PV module prices [7]-[8]

As Fig. 1 shows, the average selling prices of PV modules are currently almost the same in many countries except in Japan, which has a relatively closed market. Since the mid2000s, the increase in demand, consistent with policy supports in Europe, has attracted Chinese players into the PV manufacturing market. Chinese production soared in a short time and largely reduced the global module price with mass production under an open-trade system [9]. The global module price is now less than $\$ 1 / \mathrm{Wp}^{2}$. It seems difficult to expect the future PV system price to reduce by means of module price drops alone, as we have seen with historical data. Other factors became more important such as soft costs.

There are differences in PV system prices depending on the country (see Fig. 2). The current economic competitiveness of PV systems needs to be discussed in a comprehensive manner by taking into account other accompanying costs involved in producing PV electricity.

\footnotetext{
${ }^{2}$ This article is based on constant 2013 US \$.
}

The PV system price used to define the initial investment of LCOE can generally be split into three parts:

- Module : $\sim 40 \%$ of PV system price

- Non-module hardware: $\sim 10 \%$ of PV system price (e.g. inverters, cables, batteries, fixed supports)

- Soft costs: $\sim 50 \%$ of PV system price (e.g. engineering, customer acquisition, installation, profit and overhead costs, and permission, inspection and interconnection (PII))

The current differences in PV system prices are mainly due to non-module prices. The improvement of PV system competitiveness can be delivered by improving them. A welldesigned policy can be a trigger to boost such price reductions.

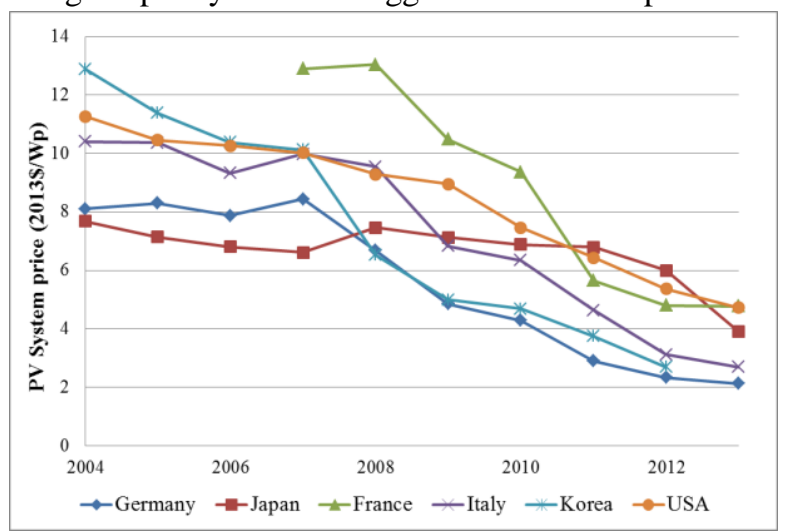

Figure 2: Change over time in residential rooftop system prices [7]-[8]

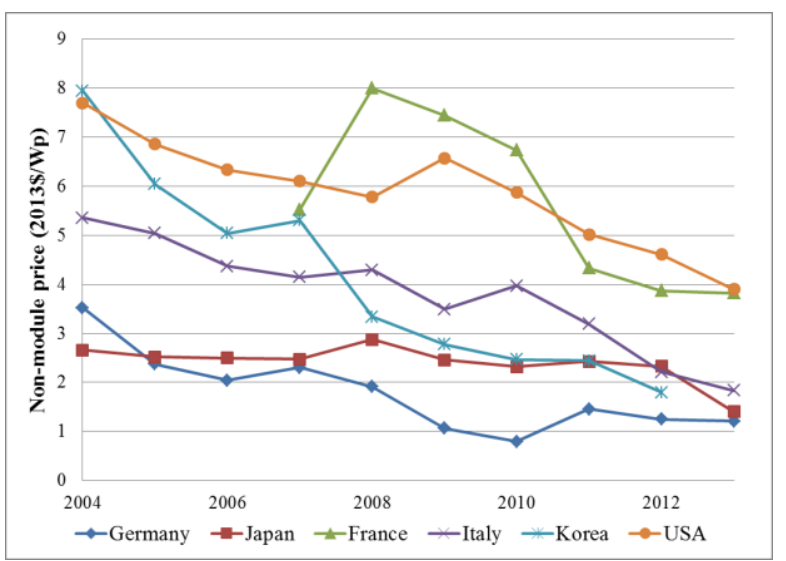

Figure 3: Change over time of the non-module price (system price - module price) [7]-[8]

In this regard, it is worth reviewing a possible correlation between the cumulative installed capacity of PV systems and the reduction of non-module costs.

\section{COST DRIVERS FOR NON-MODULE COSTS}

\section{A. Non-module costs \& country market sizes}

The global PV module market now takes advantage of the cumulative knowledge stock and experience, thereby sharing a similar price. The positive correlation between the module price drop and the size of cumulative installations has been demonstrated in many studies, reflecting the PV module's learning rate of around $20 \%$, which means that each time the cumulative installed capacity doubled, the price went down by $20 \%$ [10]. 
This paper reviews the variation in non-module prices within the PV system price using the learning-curve concept. The mathematical model is described in equations (1) and (2).

$$
\begin{gathered}
C_{t}=C_{0} \times\left(\frac{x_{t}}{x_{0}}\right)^{-b} \\
L R=1-2^{-b}
\end{gathered}
$$

With:

$C_{t}$ : Cost at time $t, X_{t}:$ Cumulative installed capacity at time $t$ $C_{0}:$ Reference cost, $X_{0}:$ Reference cumulative installed capacity $b$ : Coefficient to find, LR: The learning rate

The graph compares empirical data of non-module prices with cumulative installations in several countries, in order to provide insight into a possible correlation between them.

Data on the annual installation growth and non-module prices were taken from 1993 to 2013 whenever available. Six countries were considered; they accounted for $61 \%$ of the global cumulative installations in 2013 having a continuous installation policy over several years [11].

The curve focuses on residential rooftop PV systems for which the non-module costs account for highest fraction.

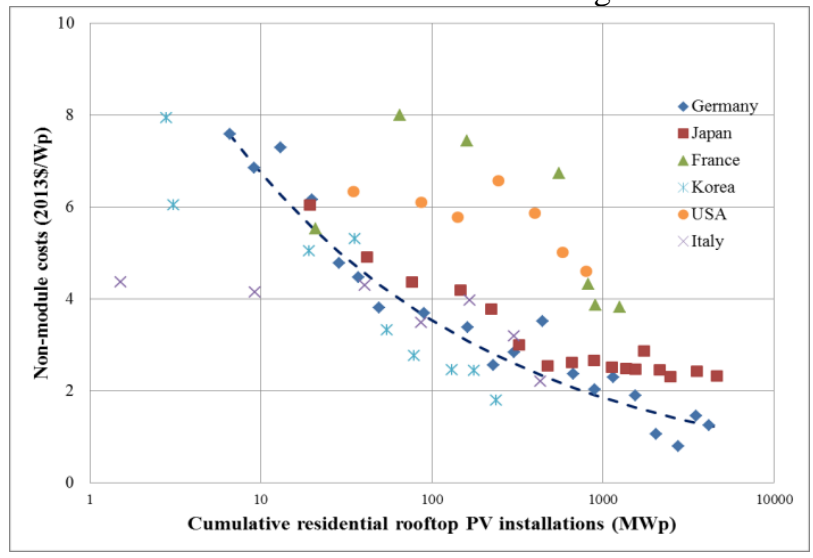

Figure 4: Learning curve for non-module costs of PV rooftop systems in different countries [12]-[13]-[14]-[15]-[16]-[17]-[18]-[19]-[20].

Fig. 4 shows that each country has its own learning curve; they can be split into two groups;

1. Italy, Germany, Korea and Japan share a similar slope

2. France and the US have a different slope.

Even though there are some country-based differences in terms of the learning rate, it seems proven that there is a positive correlation between the cumulative installations and the non-module price drops.

Germany has a learning rate of $17.6 \%$ and its learning curve equation is described in $(3)^{3}$ :

$$
C_{t}=7.6 \times\left(\frac{X_{t}}{6.6}\right)^{-0.28}
$$

The learning rate is almost the same for all countries in the first group. The difference between them is low and stays constant. This could be due to irreducible costs like different consumer prices or taxes.

\footnotetext{
${ }^{3}$ Authors' calculation, 1993 data were used for $C_{0}$ and $X_{0}$.
}

It would be worth analyzing why France and the US have different curve features from the rest so as to understand difference factors, and thus to amend strategies to increase the economic competitiveness of PV systems.

\section{B. Comparative analysis of non-module costs: Germany, France and the US}

The exceptional cases of two countries (France, USA) have been compared with the best-practice case (Germany) so as to better understand differences in non-module costs. Table I specifically breaks down the non-module price in three countries: Germany, France and the US.

Germany has the lowest price for small residential PV systems compared with those in France and the US; the main differences result from non-module segments (the module price in Germany in 2012 was $1.1 \$ / \mathrm{Wp}$ and the non-module prices stay almost constant between 2011 and 2012).

TABLE I: BREAKDOWN OF THE NON-MODULE PRICE IN GERMANY, FRANCE AND THE US

\begin{tabular}{|l|c|c|c|}
\hline \$/Wp & Germany 2011 & US 2012 & France 2012 \\
\hline PV System & $\mathbf{3}$ & $\mathbf{5 . 3}$ & $\mathbf{4 . 8}$ \\
\hline Module & $\mathbf{1 . 8 2}$ & $\mathbf{1 . 0 4}$ & $\mathbf{1 . 2 1}$ \\
\hline Non-module (total) & $\mathbf{1 . 1 8}$ & $\mathbf{4 . 2 3}$ & $\mathbf{3 . 5 8}$ \\
\hline $\begin{array}{l}\text { Non-module } \\
\text { hardware }\end{array}$ & 0.56 & 0.88 & 0.89 \\
\hline Soft costs & \multicolumn{3}{|l|}{} \\
\hline Engineering & 0.01 & 0.08 & 0.27 \\
\hline Installation & 0.23 & 0.48 & 0.75 \\
\hline PII* & 0.03 & 0.2 & 0.44 \\
\hline $\begin{array}{l}\text { Customer } \\
\text { acquisition }\end{array}$ & 0.06 & 0.37 & 0.53 \\
\hline $\begin{array}{l}\text { Profit \& overhead } \\
\text { costs }\end{array}$ & 0.29 & 2.22 & $0.7 * *$ \\
\hline
\end{tabular}

Source : [21][19]

* PII: Permission, Inspection and Interconnection

** Assumption based on the difference between ADEME data and IEAPVPS data

The major difference in German and US prices results from customer acquisition, grid connection costs and installations [21]. The difference in profit and overhead costs between Germany \& the US is also significant.

However, the learning-curve comparison of the US is not a good indicator because the US has specific market features compared with Germany and France. The US market is fragmented with different PV installation environments; each state has a different policy and legal conditions which engender different PV system prices [21]-[22]. Therefore, the meaning of the cumulative installation capacity can be interpreted differently to that of Germany and France.

Conversely, the German market is unified with a comparatively dense population. The US has higher customer acquisition and installation costs with longer Permission, Inspection and Interconnection (PII) process. Germany requires less time for these processes because of its unified market and practice, simplified processes and no permission fees [21].

However, France has a similar market compared with Germany. German has largely deployed simplified rooftop building-integrated PV systems (ISB) in the residential sector; while France has promoted the installation of PV systems 
integrated into the building structures (IAB) through a preferential FIT scheme [23]. This argument is sometimes used to justify the higher cost of PV installation in France because ISB systems are usually cheaper than IABs. However, the price difference between the two systems is only 0.25 $\$ / \mathrm{Wp}$ and is due to PV racking materials [19].

The cost difference between Germany and France is mainly driven by installation, engineering, PII process and customer acquisition.

The difference in the installation costs is particularly large. Installation costs are directly linked to workers' wages and the duration of the installation process. Considering the fact that wages are almost the same in France and in Germany, the longer installation times in France can explain the difference, which refers to a lack of standardization and less-qualified labor. In addition, engineering costs (mainly for system design) is probably increased because of a lack of standardization.

Customer acquisition costs refer to all activities before contract signing: e.g. marketing, advertising, site visits and negotiation. The high costs in France can be explained by a lack in the customer's preliminary knowledge or difficulties in choosing good installers [24]. In contrast, potential customers in Germany can easily contact 3 to 5 installers in their zip code areas through lead-aggregation websites [21].

The PII costs include grid connection costs; they amount to at least $1300 \$$ for small residential rooftop systems in France (i.e. $0.4 \$ / \mathrm{W}$ for a $3 \mathrm{~kW}$ residential system, the most installed residential system in France). In Germany, the PII price is $0.03 \$ / \mathrm{W}$, which is mainly linked to the labor cost with no permission fees and no inspection process. In addition, they have a simple online declaration process for the FIT scheme via a national web-platform [21].

In addition, the long-term policy signals are fundamentally important for the national PV development. It will give expectations about long-term market encouraging industrial investments [25]. Germany has a stable long-term PV policy support. However, France lacks long-term PV policy vision; the policy support of PV installation was often found in profits of installers, who looked for short-term profit margins. Accordingly, it seems that the PV policy support has not fully contributed to reducing end user PV system price in France [26].

\section{Opportunities for the European market}

As Fig. 4 indicates, the size of the market is related to the non-module price drop. The section below sets out to explain some opportunities for the European market on the condition that they share unified standards based on the German practice with a simple calculation process. If the west European region uses the same learning curve as Germany, it would require less investment to deploy PV systems. Fig. 5 shows the nonmodule price in 2020 on the condition that the German learning curve is shared along with properly designed policies.

The case is simplified by taking into account the residential installation conditions in three countries while country system differences are ignored. The installation total for 2020 has been calculated based on the sum of three countries, assuming the same annual growth rate up to today ${ }^{4}$

\footnotetext{
${ }^{4}$ Assumption is the cumulative installation of PV rooftop systems in France, Germany and Italy. The total cumulative installation will be about 11600 MWp based on prospective growth.
}

until 2020 for France and Italy, and EPIA estimations were taken for Germany with the same residential PV system share [27]. They will roughly reach $0.96 \$ / \mathrm{Wp}$ for the non-module price. However, better results are obtained in terms of the prospective non-module prices if more countries are included since a larger market size is taken into consideration.

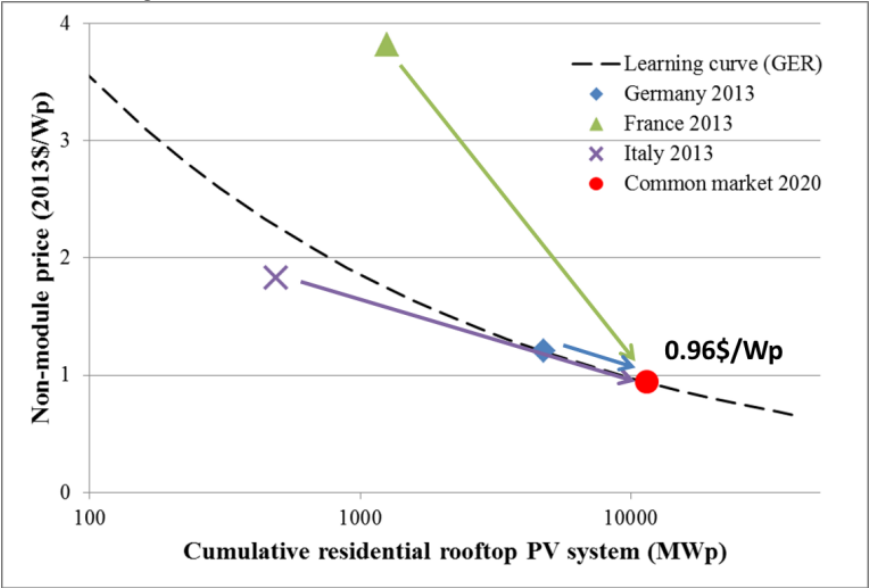

Figure 5: Common learning curve for Germany, France and Italy

Therefore, the long-term durable market growth is important. The European market could learn from this experience to develop its PV systems to meet its objective to increase renewable energies in the energy mix. By adopting the German practice, countries like France will be able to install the higher number of PV systems on the same budget thanks to the lower non-module price.

This begs the question as to what conditions can generate such opportunities.

Each country currently has a different policy focus, with different installation environments and market development stages; these factors lead to different costs for PV installation.

To reduce non-module costs in PV systems, countries can share markets and policies with a clear growth trajectory plan. Targeted policy support helps this process. Harmonized policy instruments on a regional level can reduce non-module costs in Europe by learning from the German practice (e.g. low non-module prices) and taking advantage of the size of the European market.

\section{POLICY RECOMMENDATIONS}

\section{A. Policy opportunities for reducing non-module costs}

Which policy instruments can help obtain the estimated benefits discussed in the previous section?

Targeted policies can further reduce non-module costs to improve the economic competitiveness of PV electricity. The increased market size is an important factor to reduce such costs.

Economies of scale in installations can be obtained by promoting the standardization of $\mathbf{P V}$ installation.

Standardization improves the economic competitiveness of almost all segments in non-modules; hardware price, engineering, PII process, customer acquisition and installations. Once standardized products and processes are rolled out, the market will automatically adapt without spending costs to continue tasks in these sectors (e.g. system design, adapting different installation specifications, etc.). In addition, a simplified process from project design to grid 
connection is needed. Transparent online permission processes with clear guidelines is one way of simplifying the whole process. The online tool can be also used line up customers with certified local installers. The European system for certifying PV firms based on European standards could be implemented. Furthermore, training is also important; well-trained installers and customers will remove additional time in terms of system design and installation work.

In addition, the long-term stability of the market size can be driven by regional solar mandates in the building sector (new, renovation of existing buildings) or favorable policy support that gives investors a clear long-term vision like installation subsidies, well-designed financial support or tax relief. A standardized European market is one way of gaining economic competitiveness to provide PV electricity at a low price.

\section{B. Further remarks for systemic strategies}

As discussed, the economic competitiveness of PV systems can be obtained by reducing module and nonmodules costs. The proposed policy action can help reduce such non-module costs. However, this does not directly mean cheap electricity will be obtained using PV energy. With broad penetration of PV system, other costs or externalities issues can be more visibly important for the future system. Reduced production costs can be counterbalanced by factors such as grid costs (e.g. grid extension, intermittency costs) unless proper policies are applied to improve alignment with non-module sector improvement. A systemic perspective should be used to prepare an optimal policy mix to improve economic competitiveness of PV system.

\section{CONCLUSION}

The further reduction in the production costs of PV electricity encourages the widespread use of PV power as a major electricity source. This paper sets out to demonstrate the key components of PV system prices in order to penetrate the current energy systems. Module prices are not as important as before and other non-module factors have gained equal importance when it comes to improving economic competitiveness. In this regard, policy focus also integrates these factors to gain further competitiveness. This study attempts to review opportunities with harmonized policy instruments on a regional level so as to reduce nonmodule costs of PV systems in Europe by learning from German practices and benefiting from the size of the European market. In conclusion, using an approach that is only based on module price drops or on LCOE calculations can be misleading with respect to defining PV policy. As seen, a comprehensive approach is absolutely necessary. A commonly shared practice for PV deployment could help improve European economic competiveness and thus largely reduce the PV system price.

\section{ACKNOWLEDGMENT}

The authors would like to thank Michel Cruciani, Chargé de Mission of CGEMP and Philippe Malbranche, Directeur Général of CEA-INES for their helpful comments and fruitful discussions.

\section{REFERENCES}

[1] IEA. "Technology roadmap for solar photovoltaic energy", 2014

[2] G.R. Timilsinaa, L. Kurdgelashvilib, P.A. Narbelc, «Solar energy: Markets, economics and policies", Renewable and Sustainable Energy Reviews, vol. 16, pp 449-465, 2012.

[3] OECD/NEA, "Nuclear energy and renewables: System effects in lowcarbon electricity systems", ISBN 978-92-64-18851-8, OECD, 2012.

[4], D. Pudjianto, P. Djapic, J. Dragovic, G. Strba, "Grid integration cost of photovoltaic power generation: Direct costs analysis related to grid impacts of photovoltaics", Imperial College London, September 2013.

[5] F. Ueckerdt, L. Hirth, G. Luderer, O. Edenhofer (2013): "System LCOE: What are the costs of variable renewables?", Energy,vol. 63, pp 61-75, 2013. [6] H.J.J. Yu, N. Popiolek, "A comparative study on the consequence and impact of public policies in favor of solar photovoltaic (PV) development", in IEPEC International Energy Program Evaluation Conf., Berlin, September 2014.

[7] IEA PVPS, “Trends in photovoltaic applications" 2002 to 2014.

[8] IEA PVPS, "Photovoltaic power applications: National survey report" for France, Germany, Italy and Japan, 2002 to 2013.

[9] H.J.J Yu, N. Popiolek, P. Geoffron, "Solar photovoltaic energy policy and globalization: a multi perspective approach with case studies of Germany, Japan, and China", Progress in Photovoltaics; research and applications, 2014 , DOI: 10.1002/pip.2560.

[10] F. Kersten, R. Doll, A. Kux, D.M. Huljic, M.A. Gorig, C. Breyer, J.W. Muller, P. Wawer, "PV learning curves: past and future drivers of cost reduction" in 26th EU PVSEC conf., Hamburg, 2011.

[11] IEA PVPS, "Trends in photovoltaic applications", 2014

[12] Bundesministeriums für Umwelt, Natur-schutz und Reaktorsicherheit, "Vorbereitung und Begleitung der Erstellung des Erfahrungsberichtes gemäß $\S 65$ EEG", 2011.

[13] Bundesministeriums für Wirtschaft und Energie, "Vorbereitung und Begleitung der Erstellung des Erfahrungsberichtes gemäß § 65 EEG”, 2014.

[14] Gestore Servizi Energetici,

[Online] Available:

www.gse.it/it/Conto\%20Energia/GSE_Documenti/Fotovoltaico/05\%20Risult ati\%20incentivazione/TOTALE_DEI_RISULTATI_DEL_CONTO_ENERG IA.pdf

[15] G. Barbose, N. Darghouth, S. Weaver, R. Wiser, "Tracking the Sun VI: An Historical Summary of the Installed Price of Photovoltaics in the United States from 1998 to 2012", Sunshot, July 2013

[16] IEA PVPS, "National Survey Report of PV Power Applications in Japan", 2012.

[17] T. James, D. Feldman, R. Margolis, "Japan's Solar Photovoltaic (PV) Market: An Analysis of Residential System Prices", US Department Of Energy - Solar Program, October 23, 2013.

[18] IEA PVPS, "National Survey Report of PV Power Applications in Korea", 2012.

[19] ADEME, «Données économiques de la chaîne de valeur du photovoltaïque et étude quantitative de l'impact économique de l'innovation: Estimation de l'impact des innovations », October 2012.

[20] J.B. Lesourd, S.U. Park, « The economics of grid-connected electricity production from solar-photovoltaic systems, in Annual Meeting of the Swiss Society of Economics and Statistics, Swiss Federal Institute of Technology of Zurich, Zurich, 2005.

[21] J. Seel, G.L. Barbosea, R.H. Wisera, "An analysis of residential PV system price differences between United States and Germany", Energy Policy, Vol. 69, pp 216-226, June 2014.

[22] D. Steward, E. Doris, V. Krasko, D. Hillman, "The Effectiveness of State-Level Policies on Solar Market Development in Different State Contexts", Technical Report NREL/TP-7A40-61029, February 2014. [23] IEA PVPS, "National Survey Report of PV Power Applications in France", 2012.

[24] photovoltaique.info [online] Available:

http://www.photovoltaique.info/Choisir-son-installateur.html

[25] G. Nemet, "Solar Photovoltaics: Multiple Drivers of Technological Improvement. Historical Case Studies of Energy Technology Innovation" in The Global Energy Assessment, A. Grubler, F. Aguayo, K.S. Gallagher, M. Hekkert, K. Jiang, L. Mytelka, L. Neij, G. Nemet, C. Wilson., Cambridge University Press: Cambridge, UK, chapter 24, 2012

[26] Observ'er, "Suivi du marché 2013 des installations individuelles solaires photovoltaïques", September 2014

[27] EPIA, "Global market outlook for photovoltaics 2014-2018”, 2014 